\title{
Genetic Diversity Among Forty Coffee Varieties Assessed by RAPD Markers Associated with Restriction Digestion
}

\author{
Leandro Eugênio Cardamoni Diniz ${ }^{1}$, Claudete de Fátima Ruas ${ }^{1}$, Valdemar de Paula \\ Carvalho $^{1}$, Fabrício Medeiros Torres ${ }^{1}$, Eduardo Augusto Ruas ${ }^{1}$, Melissa de Oliveira \\ Santos $^{1}$, Tumoru Sera ${ }^{2}$ and Paulo Maurício Ruas ${ }^{1 *}$ \\ ${ }^{1}$ Departamento de Biologia Geral; Universidade Estadual de Londrina; ruas@sercomtel.com.br; 86051-990; \\ Londrina - PR - Brasil. ${ }^{2}$ Instituto Agronômico do Paraná; C. P. 481; Londrina -PR - Brasil
}

\begin{abstract}
The genetic variability of 40 accessions of_C. arabica was evaluated using a combination of the random amplified polymorphic DNA (RAPD) technique and restriction digestion of genomic DNA. The genetic variability and the relatedness among all accessions were initially evaluated using 195 RAPD primers which revealed a very low level of genetic variation. To improve the efficiency in the detection of polymorphism, the genomic DNA of all accessions were submitted to digestion with restriction endonucleases prior to PCR amplification. A total of 24 primers combined with restriction digestion of DNA rendered 318 bands, of which 266 (83.65\%) were polymorphic. The associations among genotypes were estimated using UPGMA-clustering analysis. The accessions were properly clustered according to pedigree and agronomic features. The ability to distinguish among coffee accessions was greater for RAPD plus restriction digestion than for RAPD alone, providing evidences that the combination of the techniques was very efficient for the estimation of genetic relationship among_C. arabica genotypes.
\end{abstract}

Key words: Coffea arabica, genetic variability, RAPD, restriction endonucleases

\section{INTRODUCTION}

The main varieties of Coffea arabica L. cultivated in Brazil are derived from at least two botanical types; the Bourbon varieties, introduced from the Reunion Islands, and the Typica variety brought to Brazil from the French Guiana in 1727 (Smith, 1985; Berthaud and Charrier, 1988). Currently, coffee is the one of the most important Brazilian commodities. Located in southern Brazil, Paraná state is an important coffee producer. In this state, the Research Center named Instituto Agronômico do Paraná (IAPAR) maintains a Coffea germplasm collection that consist of seven species, several varieties and cultivars, and more than one thousand progenies of $C$. arabica and $C$. canephora. Despite its importance, this Coffea collection lacks information about genetic variability, mainly when it is concerning to DNA level. Until recently, genetic diversity among species or cultivars of Coffea arabica was determined using morphological or isozyme markers. However, these markers are unsuitable to measure genetic variation in arabica accessions (Berthou and Trouslot, 1977; Louarn, 1978).

In the last ten years, detection of variation at DNA level has been made possible by the advent of molecular markers. Molecular techniques such as RFLP (Restriction Fragment Length Polymorphism) (Sambrook et al., 1989), RAPD (Random Amplified Polymorphic DNA) (Welsh and McClelland, 1990; Williams et al., 1990) and AFLP (Amplified Fragment Length Polymorphism) (Vos et al., 1995) provide 
powerful tools for study of genetic diversity. RFLP analysis of the chloroplast genome and the atp-rbc intergenic region were used to study the variation among different taxa of Coffea and two species of Psilanthus. The low sequence divergence suggested that Coffea is a young genus (Lashermes et al., 1996a). The AFLP technique was useful for the detection of introgression in $C$. arabica (Lashermes et al., 2000). AFLP and SSR markers were used to assess polymorphism between and within coffee accessions (Anthony et al., 2002).

RAPD technique provides a useful tool to identify and estimate genetic diversity in Coffea. OrozcoCastilho et al. (1994) detected polymorphism between $22 C$. arabica accessions, one natural interspecific hybrid (Hibrido de Timor), three accessions of $C$. canephora and one accession of C. liberica. The study also showed that plants originated from Ethiopia and plants from the arabica sub-groups (C. arabica var Typica and $C$. arabica var Bourbon) were clearly distinguished. Analysis of genetic diversity using RAPD revealed a significant difference between cultivated (Arabica and Bourbon) and wild accessions of $C$. arabica from Kenia and Ethiopia (Lashermes et al., 1996b). Anthony et al. (2001) studied the genetic diversity among 19 C. arabica accessions from spontaneous and sub spontaneous trees of Ethiopia. The authors concluded that RAPD markers could be applied for DNA fingerprint of coffee accessions, providing information for the introgression of desirable traits and, therefore, increase the effectiveness of the breeding program. Sera et al. (2003) using RAPD markers associated with restriction digestion showed genetic divergence between arabica accessions of the same origin. Chaparro et al. (2004) used RAPD technique for the analysis of 50 wild and semiwild accessions of $C$. arabica and concluded that a much larger polymorphism was present in the collection examined than previously reported in others coffee collections. In this study, we assessed the genetic relationship among arabica accessions from a germplasm collection from Brazil using RAPD associated with prior digestion of DNA with restriction enzymes.

\section{MATERIALS AND METHODS}

\section{Plant material}

Forty coffee genotypes were used in this study (Table 1). The accessions were obtained from the Coffea Germplasm Collection of the Instituto Agronômico do Paraná (IAPAR), Londrina, Brazil. Many of the genotypes represented elite cultivars that have been used in breeding programs.

\section{DNA extraction, amplification, and gel electrophoresis}

Genomic DNA was isolated from fresh leaves, obtained from at least five different plants of each accession following the CTAB method (Doyle and Doyle, 1987), except that CTAB was replaced by MATAB (Mixed Alyltrimethylammonium Bromide, Sigma) in the extraction buffer. DNA concentration was estimated using a fluorometer (DyNA Quant 200, Höefer-Pharmacia), adjusted to $10 \mathrm{ng} / \mu \mathrm{l}$ and bulked by accessions (Michelmore et al., 1991). Amplification reactions were in a volume of $15 \mu 1$ of a standard PCR and 20ng template DNA. For restriction digestion, genomic DNA was incubated for $1 \mathrm{~h}$ at $37^{\circ} \mathrm{C}$ with one of the following enzymes, Bam HI, Eco RI, or Hae III, just prior to the PCR reaction. DNA amplification was carried out using a PTC 100 (MJ Research) thermal cycler programmed with a 3 min at $94^{\circ} \mathrm{C}$ for initial DNA denaturation, followed by 48 cycles of $1 \mathrm{~min}$ at $94^{\circ}$ $\mathrm{C}, 1 \mathrm{~min} 45 \mathrm{sec}$ at $38^{\circ} \mathrm{C}$, and $2 \mathrm{~min}$ at $72^{\circ} \mathrm{C}$. The final cycle was followed by a $7 \mathrm{~min}$ extension at $72^{\circ} \mathrm{C}$. Amplified products were resolved in $1.2 \%$ agarose gel in $1 \mathrm{x}$ TAE buffer $(40 \mathrm{mM}$ Tris-acetate, $1 \mathrm{mM}$ EDTA $\mathrm{pH}$ 8.0) and stained with ethidium bromide. The RAPD profiles were visualized under UV light and stored for further analysis in a PC computer.

\section{Data analysis}

DNA markers were scored for the presence (1) and absence (0) of homologous amplified products. The genetic similarity among accessions was estimated using the Dice coefficient of the NTSYS package (Numerical Taxonomy and Multivariate Analysis for personal computer), version 2.1 (Rohlf, 2000). A dendrogram was constructed using the UPGMA (unweighted pair-group method using arithmetic averages) method. The matrix of 
genetic similarity was also used in a principal coordinate analysis (PCOORD) to resolve the patterns of variation among the genotypes. The cophenetic coefficient between the matrix and the dendrogram was measured using the appropriate routine of the NTSYS package. The bootstrap method was employed to evaluate the reliability of tree topology. The calculations were performed with the BOOD software, version 3.0 (Coelho, 2001). The significance of the cophenetic correlation was estimated with the Mantel correspondence test (Mantel, 1967).

\section{RESULTS AND DISCUSSION}

The RAPD technique combined with a prior digestion of genomic DNA with restriction enzymes allowed for the detection of polymorphism among 40 accessions of coffee. From 195 RAPD primers initially screened, only $24(12.3 \%)$ revealed polymorphism. Low percentage of RAPD primers showing informative bands in Coffea were also reported by Lashermes et al. (1996a) and Anthony et al. (2001). The authors attributed the results to the very narrow genetic basis of $C$. arabica. To increase the number of informative bands, the total DNA from each of the accessions studied were treated with restriction enzymes prior PCR reaction with the 24 primers screened. Only three (Bam HI, Eco RI, and Hae III) out of seven enzymes tested modified the amplification patterns obtained with the primers alone, resulting in 27 primers/enzyme combinations (Table 2). The PCR amplification of genomic DNA from all accessions yielded a total of 318 bands of which $266(83.6 \%)$ were polymorphic. The mean coefficient of variation $(\mathrm{CV}=2.6 \%)$, estimated using the bootstrap procedure (Coelho, 2001) initiated to stabilize at about 100 markers and the rate of decrease was minimal beyond 200 markers (not shown). These data suggested that 318 markers were adequate for the estimation of genetic relationship among the arabica accessions. DNA polymorphism generated with and without restriction digestion was similar, however, the informative bands obtained per primer increased significantly, often including different amplified products (Table 2, Fig. 1). In wheat genotypes, Koebner (1995) observed that digestion of template DNA prior to PCR amplification allowed for more efficiency of primer annealing along shorter DNA fragment, where a simplified secondary structure was less likely to interfere with the process. Similar results were obtained by Sera et al. (2003) in 14 accessions of arabica coffee and by Silveira et al. (2003) in a study of genetic variability within and among Sarchimor progenies.

\section{Phylogenetic relationship}

The dendrogram and the PCO (Principal Coordinate Analysis) estimated from the similarity matrix (Table 3) for the 40 Coffea accessions are shown in Figs. 2 and 3, respectively. The high value of cophenetic correlation $(\mathrm{r}=0,81)$ between the similarity matrix and the dendrogram indicated the extent to which the clustering of genotypes accurately represented the estimates of genetic similarities among the accessions studied.

The primary trend in the dendrogram was to separate the genotypes into two main groups (Figs 2 and 3), one comprising the cultivars of the arabica and the Bourbon type coffee and the other including the cultivars derived from genotypes containing genes of the Hibrido de Timor.

The first cluster showed that C. arabica var typica was highly related to the Bourbon Vermelho cultivar (similarity of 0.94). This result was supported by the origin of Bourbon Vermelho as a spontaneous mutation found in Reunion Island in a field of $C$. arabica var arabica from Ethiopia (Rothfos, 1980). Both, Arabica typica and Bourbon Vermelho were close to Bourbon amarelo (mean similarity of 0.90 ) with a bootstrap support of $91 \%$ (Figs. 2, 3 and Table 3). High values of genetic similarity between $C$. arabica typica and the Bourbon group were also reported by Anthony et al. (2001). The authors concluded that even though Bourbon and Typica varieties had accumulated small differences over three centuries of selections, they still presented little divergence with wild material from Ethiopia.

The first cluster also grouped the cultivars Catuaí Vermelho IAC 81, Catuaí Amarelo IAC 17, Catuaí Semperflorens, and Acaiá IAC 474-19. Catuaí Vermelho IAC 81 and Catuaí Amarelo IAC 17 (similarity of 0.92) were artificial hybrids (Caturra Amarelo IAC 476 x Mundo Novo) whose progenies with red and yellow fruits, selected in $\mathrm{F}_{3}$ populations were named Catuaí Vermelho IAC 81 and Catuaí Amarelo IAC 17, respectively (Fazuoli, 1986). 
Table 1 - Accessions name, type, and origin of the $C$. arabica germplasm studied.

\begin{tabular}{|c|c|c|c|}
\hline $\mathbf{N}^{\mathbf{0}}$ & Accessions & Type & Origin \\
\hline 1 & Arabica typica & cultivar of C. arabica & Ethiopia \\
\hline 2 & Bourbon Amarelo & cultivar (Bourbon x Amarelo de Botucatu) & Brazil \\
\hline 3 & Bourbon Vermelho & cultivar of C. arabica & Reunion Island \\
\hline 4 & Acaiá IAC 474 -19 & cultivar (Bourbon x Sumatra) & Brazil \\
\hline 5 & Mundo Novo IAC ${ }^{1} 376-4$ & cultivar (Bourbon x Sumatra) & Brazil \\
\hline 6 & Mundo Novo Semperflorens & mutant of Acaiá & Brazil \\
\hline 7 & Catuaí Semperflorens & mutant of Catuaí Amarelo & Brazil \\
\hline 8 & Catuaí Amarelo IAC 17 & cultivar (Mundo Novo x Caturra) & Brazil \\
\hline 9 & Catuaí Vermelho IAC 81 & cultivar (Mundo Novo x Caturra) & Brazil \\
\hline 10 & Rubi - MG 1192 & Cultivar (Catuaí x Mundo Novo) & Brazil \\
\hline 11 & IAPAR 77.055 & progeny (Icatu x Caturra) & Brazil \\
\hline 12 & Catuaí $\mathrm{SH}_{2} \mathrm{SH}_{3}$ & $\mathrm{~F}_{5}$ progeny $\mathrm{SH}_{2} \mathrm{SH}_{3}$ & Brazil \\
\hline 13 & Caturra Vermelho IAC 477 & mutant variety of Bourbon & Brazil \\
\hline 14 & Caturra Amarelo IAC 476 & mutant variety of Bourbon & Brazil \\
\hline 15 & Superprecoce & germplasm of $C$. arabica & Ethiopia (FAO, 1968) \\
\hline 16 & Icatu Precoce IAC 3282 & cultivar of Icatu & Brazil \\
\hline 17 & Icatu Amarelo IAC 2944 & cultivar of Icatu & Brazil \\
\hline 18 & Icatu Vermelho IAC 2945 & cultivar of Icatu & Brazil \\
\hline 19 & Mokka & mutant of Bourbon variety & Brazil \\
\hline 20 & Laurina IAC 870 & mutant of Bourbon variety & Brazil \\
\hline 21 & Villa Lobos & mutant of Bourbon variety & Costa Rica \\
\hline 22 & San Bernardo & mutant of Bourbon variety & Costa Rica \\
\hline 23 & Villa Sarchi & mutant of Bourbon variety & Costa Rica \\
\hline 24 & Colômbia Amarelo & cultivar of Catimor & Colombia \\
\hline 25 & IAPAR 77.028 & $\mathrm{~F}_{4}$ progeny of Sarchimor & Brazil \\
\hline 26 & IAPAR 59 (75.163-22) & $\mathrm{F}_{4}$ cultivar of Sarchimor & Brazil \\
\hline 27 & Tupi IAC 1669-33 & $\mathrm{F}_{5}$ cultivar of Sarchimor & Brazil \\
\hline 28 & IAPAR 75.163-21-10 & $\mathrm{F}_{5}$ progeny of Sarchimor & Brazil \\
\hline 29 & IAPAR 75.163-12 & $\mathrm{F}_{4}$ progeny of Sarchimor & Brazil \\
\hline 30 & Kattimor & progeny of Sarchimor & Brazil \\
\hline 31 & Mundo Novo x IAPAR $59 \mathrm{~F}_{1}$ & $\mathrm{~F}_{1}$ hybrid & Brazil \\
\hline 32 & Mundo Novo x IAPAR $59 \mathrm{~F}_{2}$ & $\mathrm{~F}_{2}$ hybrid & Brazil \\
\hline 33 & Semi-erecta & mutant of Bourbon & Brazil/Ethiopia (FAO, 1968) \\
\hline 34 & Catuaí Erecta & genotype of Catuaí Amarelo & Brazil \\
\hline 35 & Goiaba & mutant of Bourbon & Brazil \\
\hline 36 & Maragogipe & Cultivar & Brazil \\
\hline 37 & Cera & mutant of Bourbon & Brazil \\
\hline 38 & Geisha & cultivar of C. arabica & Brazil/Ethiopia \\
\hline 39 & Cioicie & cultivar of C. arabica & Brazil/Ethiopia \\
\hline 40 & Purpurascens & mutant of Bourbon & Brazil \\
\hline
\end{tabular}

IAC - Instituto Agronômico de Campinas (Campinas, SP) 
Table 2 - RAPD primers (Operon Technologies) used alone for PCR or in combination with restriction enzymes for the analysis of 40 Coffea accessions.

\begin{tabular}{|c|c|c|c|c|c|}
\hline Primer & $\begin{array}{c}\text { Number of } \\
\text { bands }\end{array}$ & $\begin{array}{c}\text { Number of } \\
\text { polymorphic } \\
\text { bands } \\
\end{array}$ & Primer & Number of bands & $\begin{array}{c}\text { Number of } \\
\text { polymorphic } \\
\text { bands } \\
\end{array}$ \\
\hline OPAD $01+$ Hae III & 9 & 8 & OPP 20 & 13 & 12 \\
\hline OPAD 06 & 8 & 4 & OPAE 20 & 4 & 2 \\
\hline OPAD $06+$ Hae III & 13 & 10 & OPAE $20+$ Eco R1 & 6 & 5 \\
\hline OPAD 06 + Bam HI & 10 & 10 & OPAE $20+$ Hae III & 6 & 4 \\
\hline OPAD 07 & 14 & 14 & OPA 17 & 8 & 3 \\
\hline OPAD $07+E c o$ RI & 8 & 8 & OPAT 12 & 4 & 3 \\
\hline OPAD $07+$ Hae III & 13 & 13 & OPAT $12+$ Eco RI & 3 & 2 \\
\hline OPAD 11 & 9 & 8 & OPA 01 & 4 & 2 \\
\hline OPAD $11+E c o$ RI & 8 & 6 & OPA $01+$ Bam $\mathrm{HI}$ & 2 & 2 \\
\hline OPAD $11+$ Hae III & 5 & 5 & OPA $01+$ Eco RI & 2 & 1 \\
\hline OPAD $11+$ Bam HI & 6 & 6 & OPAE 01 & 3 & 2 \\
\hline OPAD $14+$ Eco RI & 5 & 3 & OPN 08 & 3 & 3 \\
\hline OPAD $15+$ Bam HI & 11 & 8 & OPN $08+$ Bam $\mathrm{HI}$ & 7 & 4 \\
\hline OPAD $19+$ Bam HI & 7 & 7 & OPN $08+$ Eco RI & 4 & 2 \\
\hline OPO 9 & 13 & 13 & OPN 07 & 4 & 2 \\
\hline OPO $9+$ Bam HI & 11 & 10 & OPN 07 + Hae III & 7 & 6 \\
\hline OPO 10 & 9 & 9 & OPN $07+$ Eco RI & 7 & 7 \\
\hline OPO $10+$ Bam $\mathrm{HI}$ & 11 & 11 & OPAV $09+$ Hae III & 6 & 4 \\
\hline OPO 13 & 8 & 8 & $\mathrm{OPP} 03+$ Eco RI & 3 & 1 \\
\hline OPO 14 & 16 & 15 & OPY $20+E c o$ RI & 4 & 2 \\
\hline OPP 18 & 8 & 7 & OPY $20+$ Hae III & 7 & 5 \\
\hline \multirow[t]{2}{*}{ OPP $18+$ Hae III } & 7 & 7 & OPY $20+$ Bam HI & 2 & 1 \\
\hline & & & Total & 318 & 266 \\
\hline
\end{tabular}

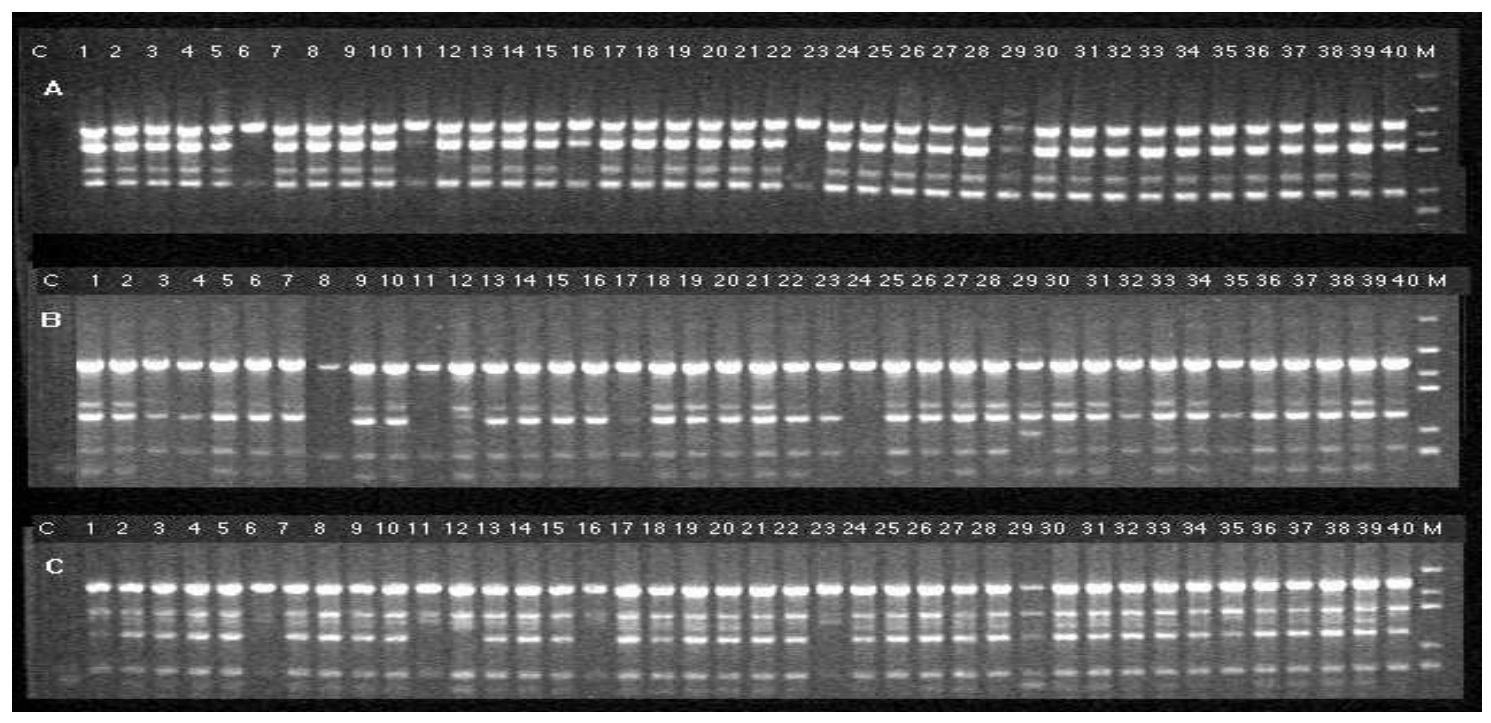

Figure 1 - Electrophoresis pattern generated with primer OPAE-20. Amplification products obtained without restriction digestion (A) and after DNA digestion with Eco R1 (B) and Hae III (C) enzymes. 
Table 3 - Matrix of genetic similarities among 40 accessions of Coffea arabica using RAPD markers.

\begin{tabular}{|c|c|c|c|c|c|c|c|c|c|c|c|c|c|c|c|c|c|c|c|}
\hline Acces & 1 & 2 & 3 & 4 & 5 & 6 & 7 & 8 & 9 & 10 & 11 & 12 & 13 & 14 & 15 & 16 & 17 & 18 & 19 \\
\hline 1. Arabica typical & 1.00 & & & & & & & & & & & & & & & & & & \\
\hline 2. Bourbon Amarelo & 0.92 & 1.00 & & & & & & & & & & & & & & & & & \\
\hline 3. Bourbon Vermelho & 0.94 & 0.87 & 1.00 & & & & & & & & & & & & & & & & \\
\hline 4. Acaiá IAC 474 -19 & 0.85 & 0.85 & 0.89 & 1.00 & & & & & & & & & & & & & & & \\
\hline 5. Mundo Novo IAC ${ }^{1} 376-4$ & 0.83 & 0.79 & 0.83 & 0.83 & 1.00 & & & & & & & & & & & & & & \\
\hline 6. Mundo Novo Semperflorens & 0.77 & 0.75 & 0.80 & 0.80 & 0.81 & 1.00 & & & & & & & & & & & & & \\
\hline 7. Catuaí Amarelo Semperflorens & 0.85 & 0.85 & 0.88 & 0.87 & 0.84 & 0.82 & 1.00 & & & & & & & & & & & & \\
\hline 8. Catuaí Amarelo IAC 17 & 0.86 & 0.83 & 0.89 & 0.89 & 0.85 & 0.81 & 0.91 & 1.00 & & & & & & & & & & & \\
\hline 9. Catuaí Vermelho IAC 81 & 0.83 & 0.82 & 0.86 & 0.85 & 0.82 & 0.81 & 0.92 & 0.92 & 1.00 & & & & & & & & & & \\
\hline 10. Rubi - MG 1192 & 0.79 & 0.76 & 0.83 & 0.81 & 0.80 & 0.75 & 0.82 & 0.84 & 0.85 & 1.00 & & & & & & & & & \\
\hline 11. Icatuaí IAPAR 77.055 & 0.74 & 0.71 & 0.79 & 0.77 & 0.77 & 0.78 & 0.82 & 0.83 & 0.84 & 0.82 & 1.00 & & & & & & & & \\
\hline 12. Catuaí $\mathrm{SH}_{2} \mathrm{SH}_{3}$ & 0.75 & 0.71 & 0.75 & 0.76 & 0.71 & 0.66 & 0.74 & 0.75 & 0.73 & 0.81 & 0.73 & 1.00 & & & & & & & \\
\hline 13. Caturra Vermelho IAC 477 & 0.81 & 0.78 & 0.83 & 0.84 & 0.81 & 0.77 & 0.86 & 0.86 & 0.87 & 0.84 & 0.84 & 0.80 & 1.00 & & & & & & \\
\hline 14. Caturra Amarelo IAC 476 & 0.80 & 0.77 & 0.82 & 0.83 & 0.77 & 0.74 & 0.86 & 0.85 & 0.83 & 0.85 & 0.82 & 0.83 & 0.86 & 1.00 & & & & & \\
\hline 15. Arabica Superprecoce & 0.74 & 0.74 & 0.78 & 0.79 & 0.80 & 0.72 & 0.81 & 0.80 & 0.80 & 0.77 & 0.75 & 0.72 & 0.83 & 0.82 & 1.00 & & & & \\
\hline 16. Icatu Precoce IAC 3282 & 0.81 & 0.80 & 0.83 & 0.83 & 0.80 & 0.77 & 0.88 & 0.86 & 0.88 & 0.82 & 0.83 & 0.71 & 0.90 & 0.84 & 0.81 & 1.00 & & & \\
\hline 17. Icatu Amarelo IAC 2944 & 0.82 & 0.81 & 0.85 & 0.85 & 0.81 & 0.75 & 0.88 & 0.87 & 0.86 & 0.84 & 0.81 & 0.77 & 0.89 & 0.88 & 0.85 & 0.90 & 1.00 & & \\
\hline 18. Icatu Vermelho IAC 2945 & 0.82 & 0.80 & 0.84 & 0.85 & 0.79 & 0.74 & 0.87 & 0.85 & 0.85 & 0.80 & 0.79 & 0.77 & 0.88 & 0.86 & 0.82 & 0.90 & 0.92 & 1.00 & \\
\hline 19. Mokka & 0.83 & 0.82 & 0.85 & 0.86 & 0.79 & 0.74 & 0.88 & 0.87 & 0.87 & 0.81 & 0.81 & 0.77 & 0.91 & 0.88 & 0.83 & 0.89 & 0.92 & 0.93 & 1.00 \\
\hline 20. Laurina IAC 870 & 0.81 & 0.80 & 0.82 & 0.85 & 0.78 & 0.74 & 0.86 & 0.84 & 0.84 & 0.80 & 0.80 & 0.78 & 0.87 & 0.87 & 0.81 & 0.87 & 0.91 & 0.92 & 0.91 \\
\hline 21. Villa Lobos & 0.82 & 0.80 & 0.82 & 0.81 & 0.75 & 0.74 & 0.83 & 0.81 & 0.82 & 0.76 & 0.73 & 0.73 & 0.81 & 0.79 & 0.79 & 0.81 & 0.84 & 0.85 & 0.84 \\
\hline 22. San Bernardo & 0.82 & 0.81 & 0.83 & 0.81 & 0.76 & 0.74 & 0.85 & 0.82 & 0.82 & 0.79 & 0.74 & 0.74 & 0.85 & 0.81 & 0.77 & 0.84 & 0.85 & 0.86 & 0.86 \\
\hline 23. Villa Sarchi & 0.79 & 0.76 & 0.81 & 0.79 & 0.74 & 0.77 & 0.81 & 0.79 & 0.78 & 0.76 & 0.76 & 0.72 & 0.78 & 0.80 & 0.75 & 0.79 & 0.84 & 0.83 & 0.82 \\
\hline 24. Colômbia Am & 0.80 & 0.79 & 0.80 & 0.78 & 0.75 & 0.70 & 0.83 & 0.78 & 0.80 & 0.76 & 0.72 & 0.72 & 0.81 & 0.78 & 0.77 & 0.80 & 0.84 & 0.85 & 0.84 \\
\hline 25. IAPAR 77.028 & 0.81 & 0.79 & 0.81 & 0.80 & 0.74 & 0.72 & 0.82 & 0.79 & 0.81 & 0.76 & 0.75 & 0.74 & 0.82 & 0.79 & 0.77 & 0.81 & 0.82 & 0.83 & 0.83 \\
\hline 26. IAPAR 59 (75.163-22) & 0.82 & 0.80 & 0.83 & 0.80 & 0.76 & 0.73 & 0.82 & 0.81 & 0.81 & 0.80 & 0.73 & 0.75 & 0.82 & 0.82 & 0.80 & 0.80 & 0.84 & 0.83 & 0.83 \\
\hline 27. Tupi (IAC 16 & 0.84 & 0.82 & 0.83 & 0.81 & 0.78 & 0.74 & 0.84 & 0.82 & 0.82 & 0.77 & 0.72 & 0.75 & 0.80 & 0.80 & 0.78 & 0.80 & 0.84 & 0.83 & 0.84 \\
\hline 28. IAPAR 75.16 & 0.81 & 0.80 & 0.82 & 0.80 & 0.76 & 0.72 & 0.83 & 0.80 & 0.81 & 0.78 & 0.72 & 0.74 & 0.82 & 0.80 & 0.79 & 0.81 & 0.86 & 0.85 & 0.86 \\
\hline 29. IAPAR 75.163-12 & 0.79 & 0.78 & 0.79 & 0.77 & 0.71 & 0.68 & 0.80 & 0.79 & 0.81 & 0.77 & 0.72 & 0.72 & 0.81 & 0.79 & 0.77 & 0.79 & 0.83 & 0.80 & 0.84 \\
\hline 30. Kattimor & 0.80 & 0.77 & 0.80 & 0.79 & 0.75 & 0.72 & 0.83 & 0.80 & 0.81 & 0.79 & 0.76 & 0.76 & 0.83 & 0.85 & 0.80 & 0.81 & 0.84 & 0.82 & 0.84 \\
\hline 31. $F_{1}$ Mundo Novo x IAPAR 59 & 0.81 & 0.79 & 0.80 & 0.78 & 0.74 & 0.69 & 0.81 & 0.81 & 0.82 & 0.76 & 0.74 & 0.74 & 0.81 & 0.81 & 0.78 & 0.80 & 0.83 & 0.84 & 0.84 \\
\hline 32. $F_{2}$ Mundo Novo x IAPAR 59 & 0.75 & 0.73 & 0.74 & 0.71 & 0.70 & 0.68 & 0.75 & 0.73 & 0.75 & 0.78 & 0.70 & 0.79 & 0.77 & 0.80 & 0.75 & 0.74 & 0.78 & 0.77 & 0.79 \\
\hline 33. Semi-erecta & 0.81 & 0.80 & 0.83 & 0.80 & 0.78 & 0.71 & 0.82 & 0.81 & 0.83 & 0.80 & 0.77 & 0.75 & 0.84 & 0.80 & 0.81 & 0.81 & 0.85 & 0.85 & 0.86 \\
\hline 34. Catuaí Amarelo Erecta & 0.82 & 0.80 & 0.81 & 0.79 & 0.77 & 0.70 & 0.82 & 0.80 & 0.81 & 0.78 & 0.75 & 0.74 & 0.82 & 0.81 & 0.80 & 0.82 & 0.85 & 0.83 & 0.86 \\
\hline 35. Goiaba & 0.81 & 0.78 & 0.81 & 0.79 & 0.78 & 0.73 & 0.81 & 0.79 & 0.78 & 0.77 & 0.75 & 0.74 & 0.81 & 0.81 & 0.80 & 0.80 & 0.84 & 0.82 & 0.86 \\
\hline 36. Maragogipe & 0.79 & 0.76 & 0.81 & 0.78 & 0.76 & 0.70 & 0.80 & 0.78 & 0.81 & 0.79 & 0.75 & 0.77 & 0.82 & 0.80 & 0.80 & 0.79 & 0.83 & 0.82 & 0.84 \\
\hline 37. Cera & 0.78 & 0.75 & 0.78 & 0.75 & 0.74 & 0.67 & 0.77 & 0.76 & 0.78 & 0.74 & 0.71 & 0.74 & 0.80 & 0.78 & 0.79 & 0.77 & 0.80 & 0.79 & 0.82 \\
\hline 38. Geisha & 0.77 & 0.75 & 0.78 & 0.76 & 0.73 & 0.65 & 0.78 & 0.78 & 0.78 & 0.76 & 0.72 & 0.76 & 0.81 & 0.79 & 0.77 & 0.80 & 0.83 & 0.82 & 0.85 \\
\hline 39. Cioiccie & 0.81 & 0.78 & 0.81 & 0.79 & 0.76 & 0.69 & 0.80 & 0.79 & 0.80 & 0.79 & 0.75 & 0.78 & 0.83 & 0.81 & 0.78 & 0.80 & 0.84 & 0.84 & 0.85 \\
\hline 40. Purpurascens & 0.79 & 0.78 & 0.80 & 0.79 & 0.77 & 0.71 & 0.82 & 0.78 & 0.79 & 0.76 & 0.74 & 0.74 & 0.83 & 0.82 & 0.82 & 0.83 & 0.83 & 0.84 & 0.85 \\
\hline
\end{tabular}

Table 3 - Continuing...

\begin{tabular}{|c|c|c|c|c|c|c|c|c|c|c|c|c|c|c|c|c|c|c|c|c|c|}
\hline Accessions ${ }^{1}$ & 20 & 21 & 22 & 23 & 24 & 25 & 26 & 27 & 28 & 29 & 30 & 31 & 32 & 33 & 34 & 35 & 36 & 37 & 38 & 39 & 40 \\
\hline 1. Arabica typical & & & & & & & & & & & & & & & & & & & & & \\
\hline 2. Bourbon Amarelo & & & & & & & & & & & & & & & & & & & & & \\
\hline 3. Bourbon Vermelho & & & & & & & & & & & & & & & & & & & & & \\
\hline 4. Acaiá IAC 474 -19 & & & & & & & & & & & & & & & & & & & & & \\
\hline 5. Mundo Novo IAC ${ }^{1} 376-4$ & & & & & & & & & & & & & & & & & & & & & \\
\hline 6. Mundo Novo Semperflorens & & & & & & & & & & & & & & & & & & & & & \\
\hline 7. Catuaí Amarelo Semperflore & & & & & & & & & & & & & & & & & & & & & \\
\hline 8. Catuaí Amarelo IAC 17 & & & & & & & & & & & & & & & & & & & & & \\
\hline 9. Catuaí Vermelho IAC 81 & & & & & & & & & & & & & & & & & & & & & \\
\hline 10. Rubi - MG 1192 & & & & & & & & & & & & & & & & & & & & & \\
\hline 11. Icatuaí IAPAR 77.055 & & & & & & & & & & & & & & & & & & & & & \\
\hline 12. Catuaí $\mathrm{SH}_{2} \mathrm{SH}_{3}$ & & & & & & & & & & & & & & & & & & & & & \\
\hline 13. Caturra Vermelho IAC 477 & & & & & & & & & & & & & & & & & & & & & \\
\hline 14. Caturra Amarelo IAC 476 & & & & & & & & & & & & & & & & & & & & & \\
\hline
\end{tabular}


(Cont. Table 3)

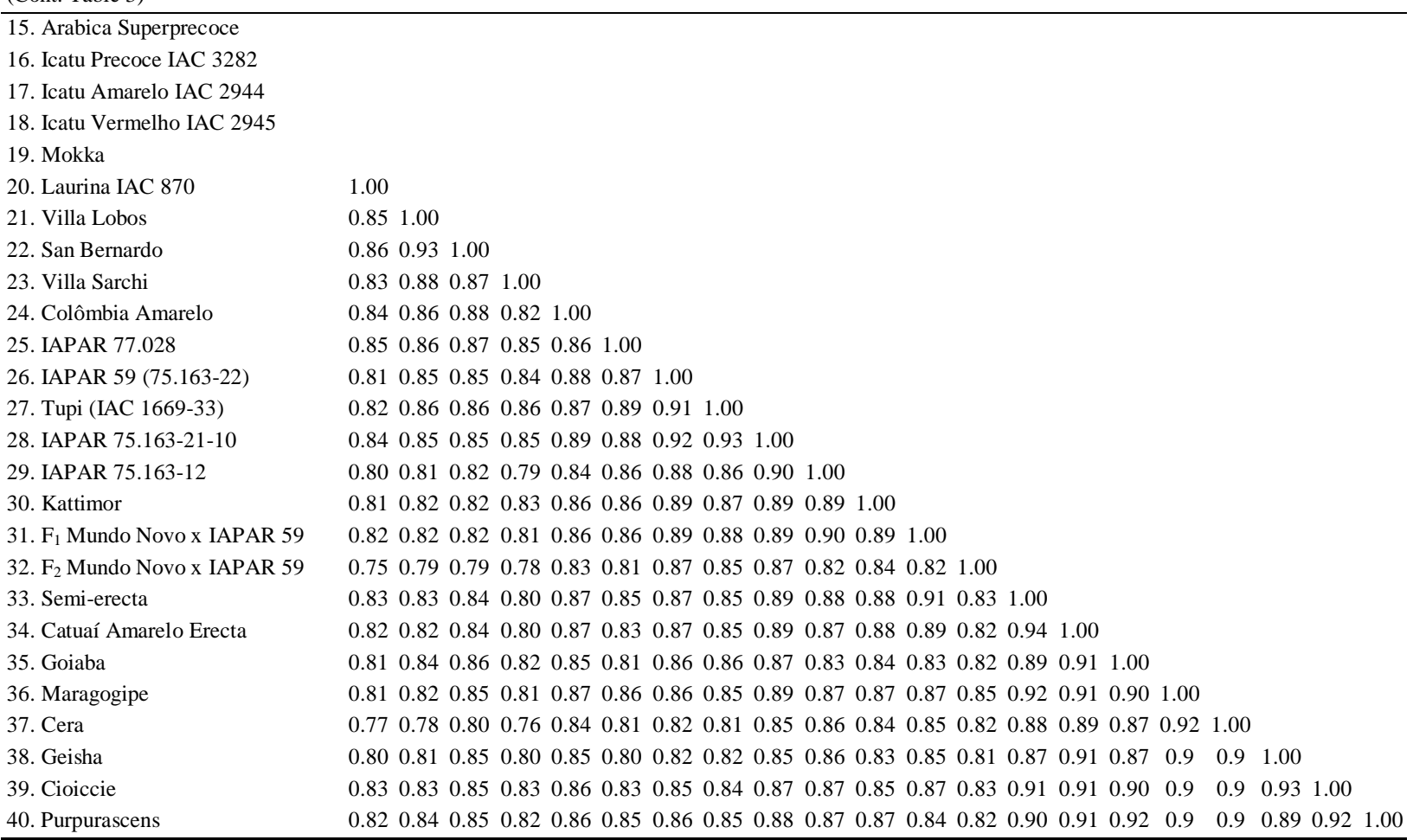

${ }^{1}$ accessions are numbered according to Table 1 .

Catuaí Semperflorens was a mutant of Catuaí Amarelo IAC 17, thus justifying the close similarities with Catuaí Amarelo IAC 17 (0.91) and Caturra Vermelho IAC 477 (0.92).

Acaiá IAC 474 -19 was associated with the Catuai cultivars showing a mean similarity of 0.87 with a bootstrap support of $94 \%$. The Acaiá genotype was derived by selection from progenies of the Mundo Novo germplasm, which arose from natural hybridization between Sumatra and Bourbon cultivars (Fazuoli, 1986; Carvalho et al., 1989). Caturra Vermelho IAC 477, Icatu precoce IAC 3282, Icatu Amarelo IAC 2944, Icatu Vermelho IAC 2945, Mokka, and Laurina IAC 870 were grouped together (mean similarity of 0.89). The variety Icatu was obtained after artificial crossing between $C$. canephora var robusta $(4 \mathrm{x})$ and $C$. arabica var Bourbon Vermelho. The F1 was crossed with Mundo Novo and selected for precocity giving rise to Icatu precoce IAC 3282. The predominance of genes from Bourbon Vermelho in both, Caturra Vermelho IAC 477 and Icatu Precoce IAC 3282 gave support to the high genetic similarities observed. The cultivar Icatu Amarelo was tightly associated in this group showing a mean similarity of 0.90 with Icatu Vermelho, Mokka, and Laurina
IAC 870 (Figs 2, 3). Icatu Amarelo was obtained by selection of plants derived from natural crossing between Icatu Vermelho and Bourbon Amarelo (Fazuoli, 1981). Laurina IAC 870 was derived from the Bourbon Vermelho gene pool in Reunion Island, sharing most of its morphological characters with the Mokka cultivar (Rothfos, 1989; Krug et al., 1950). Therefore, the molecular data were fully supported by pedigree information of these cultivars.

The cultivars Rubi-MG 1192 and IAPAR- 77055 were clustered with a similarity 0.82 (Table 3 and Figs. 2, 3). Rubi MG 1192 was a cultivar derived from crossing between Catuai Vermelho IAC 81 and Mundo Novo while IAPAR-77055 was obtained from Icatu x Catuai Vermelho IAC 81 crossing after selection for plant size.

The accessions associated in the second group were clustered into three subgroups (Figs 2, 3). In the first subgroup, the varieties Villa Lobos and San Bernardo were tightly clustered with a similarity of 0.93 and a bootstrap support of. $99 \%$. These varieties associated to Villa Sarchi with a mean similarity coefficient of 0.88 and a bootstrap of $63 \%$. Villa Lobos, San Bernardo, and Villa Sarchi have the same origin (Bourbon Vermelho germplasm) giving support to the high similarities 
observed. All but one (Colombia Amarelo of the Catimor gene pool) of the accessions associated in the second subgroup belonged to the Sarchimor germplasm (Table 1). IAPAR-59 and the accessions IAPAR 75163-21-10 and IAPAR 75163-12 were obtained from an open pollinated field of IAPAR 75163, which was a $\mathrm{F}_{3}$ progeny from Villa Sarchi (CIFC 971/10) x Híbrido de Timor (CIFC 832/2) (Silveira et al., 2003).

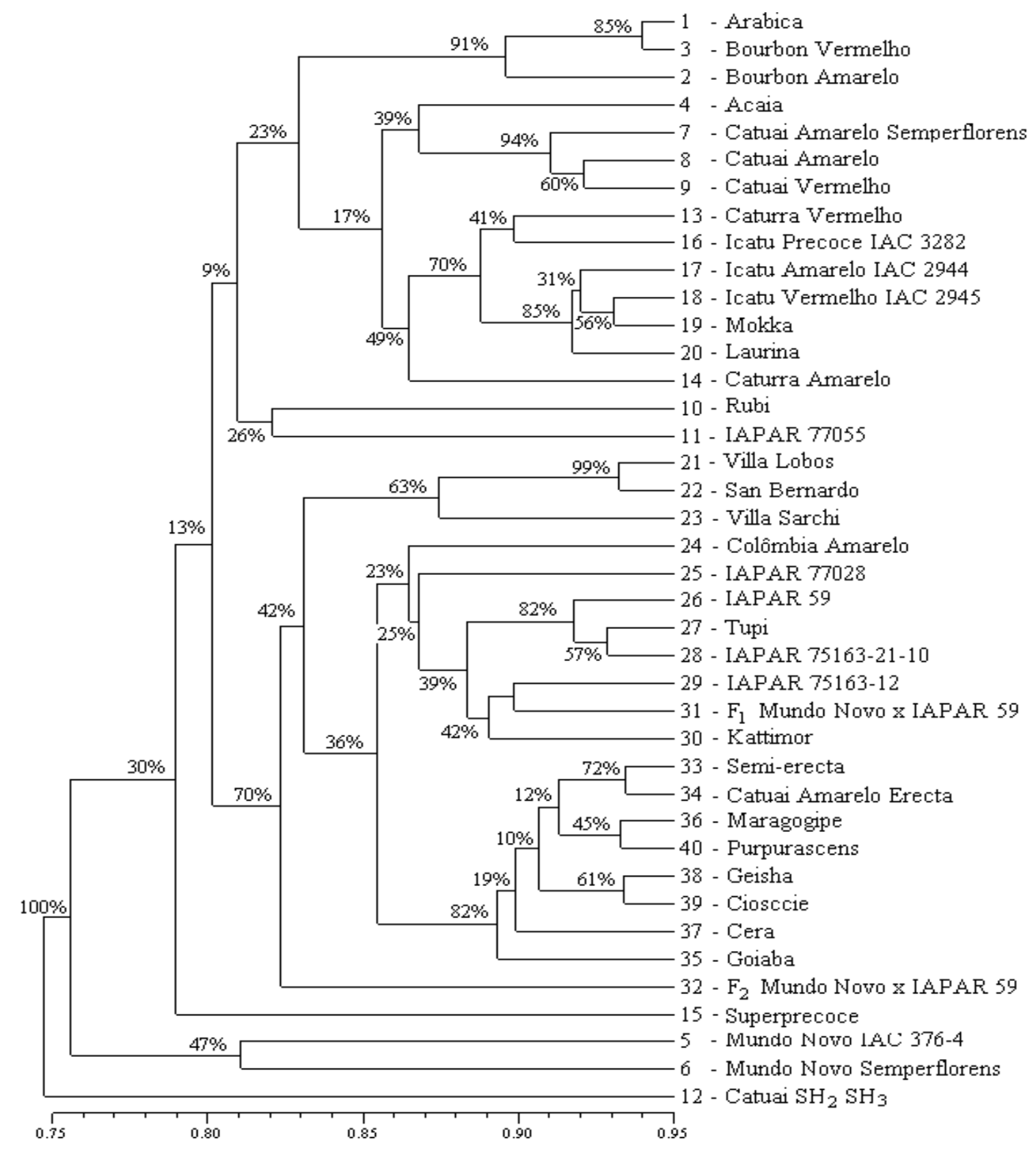

Figure 2 - UPGMA dendrogram of 40 C. arabica accessions based on Dice genetic similarity. Numbers at branches are bootstrap value (\%) generated after 1000 permutations (Coelho, 2001). 


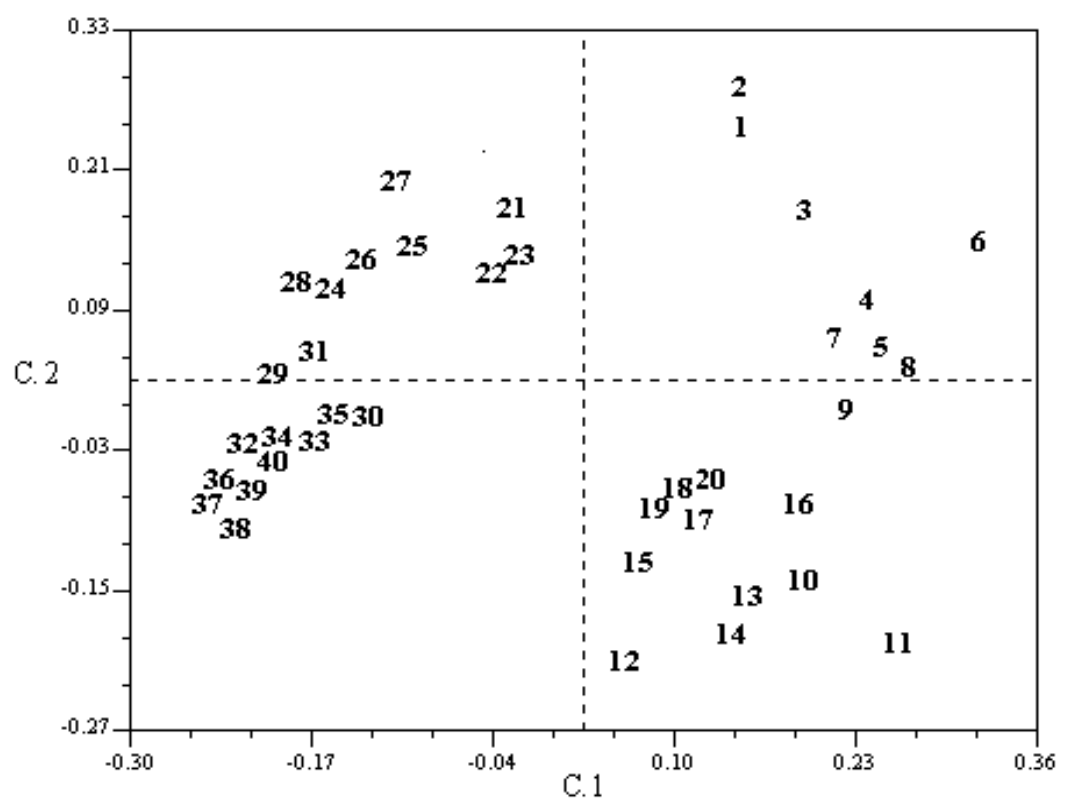

Figure 3 - Principal Coordinate Analysis of the 40 accessions of $C$. arabica. The numbers correspond to the accessions as listed in Table 1.]

The high similarity coefficients $(0.86$, on average) obtained with RAPD data were correlated with characteristics such as rust resistance, architecture and vegetative vigor shared by these cultivars. Even so these varieties display some differences in canopy diameter and grain size. A more comprehensive study about the relationships among the Sarchimor varieties and some Bourbon varieties has been described by Sera et al. (2003). The third subgroup associated eight accessions (Semi-erecta, Catuaí Amarelo Erecta, Maragogipe, Purpurascens, Geisha, Cioiccie, Cera, and Goiaba). Semi Erecta clustered with Catuaí Amarelo Erecta with a similarity coefficient of 0.94. The Semi-erecta genotype was a presumed mutant of Bourbon Vermelho sharing characteristics such as plant architecture, productivity, and grain size similar to the Bourbon-type coffee. Although Semi Erecta and Bourbon Vermelho were included in different clusters, the similarity coefficient between them was 0.83 giving support to the morphological relationship. The accession of Catuaí Amarelo Erecta used in this assay was also of uncertain origin. It was found in a field of Catuaí Amarelo IAC 17, possibly derived from hybridization between plants of the Arabica Erecta gene pool and Catuaí genotypes. Catuaí Amarelo Erecta revealed a mean genetic similarity of $81 \%$ with Catuaí Vermelho IAC 81 and Catuaí Amarelo IAC 17.

The cultivars Maragogipe, Purpurascens, Cera, Goiaba, Geisha, and Cioicie showed a mean genetic similarity of 0.90 . According to Clifford and Willson (1985), Purpurascens, Maragogipe, and Goiaba were mutants of Bourbon Vermelho. Carvalho et al. (1989) considered that Geisha and Cera were mutant versions of Bourbon Vermelho. All these varieties showed a mean genetic similarity of $80 \%$ with Bourbon Vermelho. The $\mathrm{F}_{2}$ hybrid Mundo Novo x IAPAR-59 was associated to the second main group with a mean similarity coefficient of 0.83 . This hybrid was from a segregant population (Sera et al., 2003) and showed only 0.70 of genetic similarity with Mundo Novo IAC-376 and 0.87 with IAPAR-59. These results were in agreement with morphological characters, suggesting that this segregant carried more genes from IAPAR-59 than from Mundo Novo IAC-376 (Sera et al., 2003).

The remaining cultivars, Superprecoce, Mundo Novo IAC-376, Mundo Novo Semperflorens (a spontaneous mutation of Mundo Novo), and Catuaí $\mathrm{SH}_{2} \mathrm{SH}_{3}$, appeared isolated in the dendrogram. These cultivars were also spread over the PCA plot suggesting that they were less related 
to the other cultivars. For instance, Mundo Novo IAC-376 and Mundo Novo Semperflorens showed a mean genetic similarity of only 0.75 , with the other cultivars studied. Similarly, the cultivar Superprecoce showed a mean genetic similarity coefficient of 0.77 with the other accessions. This cultivar was obtained from accessions of $C$. arabica collected by FAO in 1968 in Ethiopia. The differences at DNA level reproduce the morphological divergence observed between Superprecoce and the other accessions studied.

The cultivar Catuaí $\mathrm{SH}_{2} \quad \mathrm{SH}_{3}$ was the most divergent genotype among all accessions studied. The range of the similarity coefficient was from 0.66 with Mundo Novo Semperflorens to 0.81 with the cultivar Caturra Amarelo IAC 476. Catuaí $\mathrm{SH}_{2} \mathrm{SH}_{3}$ was a product of crossing between genotypes of Catuaí Amarelo IAC 17 and Catuaí $\mathrm{SH}_{2}$. The $\mathrm{F}_{1}$ hybrid was then crossed to Catuaí $\mathrm{SH}_{3}$, a genotype derived by crossing between Catuaí and the interespecific hybrid $C$. arabica $\mathrm{SH}_{3}$ (C. liberica x C. arabica), followed by backcrossing with the parental Arabica (Bettencourt, 1981). The grouping of C. arabica genotypes based on molecular markers was consistent with taxonomy and pedigree information described for this coffee collection. The combination of the RAPD technique with the prior digestion of template DNA with restriction endonucleases offered a reliable and effective method of accessing genetic variation in $C$. arabica accessions.

\section{ACKNOLEDGEMENTS}

We thank Conselho Nacional de Pesquisa (CNPq), process number 463861/000, Consórcio Brasileiro de Pesquisa e Desenvolvimento do Café (CBP and D/Café), and Fundação Araucária for financial support. We are also grateful to CAPES (Coordenação de Aperfeiçoamento de Pessoal de Nível Superior) and CNPq (Conselho Nacional de Pesquisa) for the grants to Leandro E. C. Diniz and Valdemar P. Carvalho.

\section{RESUMO}

A variabilidade genética de 40 acessos de cafeeiros de fenótipo arabica foi obtida usando a técnica de RAPD associada a uma digestão prévia do DNA genômico com endonucleases. A variabilidade genética e a relação entre os accessos foram inicialmente avaliadas pela amplificação de 195 primers. Para incrementar a eficiência na detecção de polimorfismo, o DNA genômico de cada acessos foi submetido a digestão com endonucleases antes da PCR. Um total de 24 primers combinados com restrição do DNA gerou 318 bandas, das quais $266(83,65 \%)$ foram polimórficas. A associação entre os 40 acessos foi estimada pelo método de clusters UPGMA, sendo os acessos agrupados de acordo com seu pedigree e aspectos agronômicos. Os resultados mostraram que o uso de enzimas de restrição antes da reação de amplificação pode ser considerada uma ferramenta eficiente para incrementar o número de bandas informativas, possibilitando a diferenciação entre os 40 acessos de C. arabica.

\section{REFERENCES}

Anthony, F.; Bertrand, B.; Quiros, O.; Wilches, A.; Lashermes, P.; Berthaud, J. and Charrier, A. (2001), Genetic diversity of wild coffee (Coffea arabica L.) using molecular markers. Euphytica, 118, 53-65.

Berthaud, J. and Charrier, A. (1988), Genetic Resources of Coffea. In: Clarke, R. J. and Macrae, R. (Eds.). Coffea Agronomy. Elsevier Applied Science Publishers. pp. 1-42.

Berthou, F. and Troslot, P. (1977), L'analyse $d u$ polymorphisme enzymatique dans de genere Coffea: adaptation d'une methode d'electrophorese en serie. Abidjan : Eighth Conference of ASIC. (Ivory Coast). pp. 373-383.

Bettencourt, A. J. and Carvalho, A. (1968), Melhoramento visando a resistência do cafeeiro à ferrugem. Bragantia, 27, 35-68.

Bettencout, A. J. (1981), Transferência de fatores de resistência à Hemileia vastatrix Berk. and Br. para as principais cultivares de Coffea arabica L. Tese (Doutorado), Instituto Superior de Agronomia da Universifdade Técnica de Lisboa, Portugal.

Carvalho, A. and Krug, C. A. (1950), Genética de Coffea XIII -Hereditariedade da característica erecta em Coffea arabica L. Bragantia, 10, 321-328.

Carvalho, A.; Eskes, A. B.; Castilho, Z. J.; Screenivasan, M. S.; Echeverri, J. H.; Fernandez C. E. and Fazuoli, L. C. (1989), Breeding programs. In: Kushalappa, A. C. and Eskes, A. B. (Eds.). Coffee rust: epidemiology, resistance, and management. Boca Raton, Florida : CRC Press Inc. pp. 293-335.

Chaparro, A. P.; Cristancho, M. A.; Cortina, H. A. and Gaitan. A. L. (2004), Genetic variability of Coffea arabica L. accessions from Ethiopia evaluated 
with RAPDs. Genetic Resources and Crop Evolution, 51, 291-297.

Clifford, M. N. and Wilson, K. C. (1985), Coffee: Botany, biochemistry and production of beans and beverage. The AVI Publishing Company, Inc.

Coelho, A. S. G. (2001), DBOOT - Avaliação dos erros associados a estimativas de distâncias/similaridades genéticas através do procedimento de bootstrap com número variável de marcadores, v. 1.1. Goiânia : Departamento de Biologia Geral, Instituto de Ciências Biológicas, Universidade Federal de Goiás.

Cros, J.; Combes, M. C.; Trouslot, P.; Anthony, F.; Hamon, S.; Charrier, A. and Lashermes, P. (1998). Phylogenetic relationships of Coffea species: new evidence based on the chloroplast DNA variation analysis. Mol Phylog. Evol., 9, 109-117.

Doyle, J. J. and Doyle, J. L. (1987), A Rapid DNA isolation procedure for small quantities of fresh leaf tissue. Phytoch. Bull, 19, 11-15.

Fazuoli, L. C. (1986), Genética e Melhoramento do cafeeiro. In: Rena, A. B.; Malavolta, E.; Rocha, M. and Yamada, T. (Eds.). Cultura do Cafeeiro. Fatores que afetam a produtividade. Piracicaba : Associação Brasileira para Pesquisa da Potassa e do Fosfato.

Klug, C. A.; Carvalho, A. and Mendes, J. E. T. (1950), Taxonomia de Coffea arabica L. III -Coffea arabica L. var. anormalis. Bragantia, 11, 335-343.

Koebner, R. M. D. (1995), Predigestion of DNA template improves the level of polymorphism of random amplified polymorphic DNAs in wheat. Genetic Analysis. Biomol. Eng., 12, 63-67.

Lashermes, P.; Cros, J.; Combes, M. C.; Trouslot, P.; Anthony, F.; Hamon, S. and Charrier, A. (1996a), Inheritance and restriction fragment length polymorphism of chloroplast DNA in the genus Coffea L., Theor. Appl. Genet., 93, 626-632.

Lashermes, P.; Trouslot, P.; Anthony, F., Combes, M. C. and Charrier, A. (1996b), Genetic diversity for RAPD markers between cultivated and wild accessions of Coffea arabica. Euphytica, 87, 59-64.

Lashermes, P.; Combes, M. C.; Topard, P.; Graziosi, G.; Bertrand, B. and Anthony, F. (2000), Genetic diversity and molecular mapping of coffee. In: Riede, C. R.; Sera T.; Soccol, C. R.; Pandey, A. and Roussos, S. (Coords). In: Seminário Internacional sobre Biotecnologia na Agroindústria Cafeeira, 3., Londrina. Anais... Londrina : IAPAR/IRD. pp. 151-154.

Louarn, J. (1978), Diversité comparée des descendances de Coffea arabica obtennes en autofé condation en fécondation libre an Tonkoui 75-78. In: Charrier, A.ed., Etude de la Structure et de la Variabilité Génétique des Cafëiers. IFCC Bull., 14, 75-78.

Mantel, N. (1967), The detection of disease clustering and a generalized regression approach. Cancer Res., 27, 299-220.
Michelmore, R. W.; Paran, I. and Kesseli, R.V. (1991), Identification of markers linked to disease-resistance genes by bulked segregant analysis: A rapid method to detect markers in specific genomic regions by using segregating populations. Proc. Natl. Acad. Sci. USA, 88, 9828-9832.

Narasimhaswamy, R. L. (1960), Arabica selection S. 795. Its origin and performance: a study. Indian Coffee, 24, 197-204.

Orozco-Castillo, C.; Chalmers, K. J. and Powell, R.W. (1994), Detection of genetic diversity and selective gene introgression in coffee using RAPD markers. Theor. Appl. Genet., 87, 934-940.

Rothfos, B. (1980). Coffee Production. Giordan-MaxRieck, GmbH, Hamburg.

Rohlf, F. J. (2000), NTSYS-pc Numerical Taxonomy and Multivariate Analysis System version 2.1. Owner manual.

Sambrook, J.; Fritsch, E. F. and Maniatis, T. (1989), Molecular cloning. A Laboratory manual $2^{\text {nd }}$ ed. Cold Spring Harbor Laboratory Press, Cold Spring Harbor, NY. 3 v.

Sera, T.; Ruas, P. M.; Ruas, C. F.; Diniz, L. E. C.; Carvalho, V. P.; Rampim, L.; Ruas, E. A. and Silveira, S. R. (2003), Genetic polymorphism among 14 elite cultivars of Coffea arabica L. using RAPD markers associated with restriction digestion. Gen. Mol. Biol., 26, 59-64.

Silveira, S. R.; Ruas, P. M.; Ruas, C. F.; Sera, T.; Carvalho, V. P. and Coelho, A. S. G. (2003), Assessment of genetic variability within and among progenies and cultivars of coffee using RAPD markers. Gen. Mol. Biol., 26, 329-336.

Smith, F. R. (1985), A history of coffee In: Cliford, M. N. and Wilson, K. C. (Eds.). Coffee, Botany, Biochemistry and production of beans and beverage. London and Sydney : Croom Helm. pp. 1-12.

Vos, P.; Hogers, R.; Bleeker, M.; Reijans, M.; Van de Lee, T.; Hornes, M; Frijters, A.; Pot, T.; Peleman, J.; Kuiper, M. and Zabeau, M. (1995), AFLP. A new technique for DNA fingerprinting. Nucl. Ac. Res., 23, 4407-4414.

Welsh, J. and McClelland, M. (1990). Fingerprinting genomes using PCR with arbitrary primers. Nucl. Ac. Res., 18, 7213-7218.

Williams, J. G. K.; Kubelik, A. R.; Livak, K. J. and Rafalski, J. A. (1990), DNA polymorphisms amplified by arbitrary primers are useful as genetic markers. Nucl. Ac. Res., 18, 6531-6535.

Received: December 22, 2003; Revised: June 28, 2004; Accepted: April 20, 2005 